\title{
Sistem Administrasi Data Visum Pada Pendaftaran Instalasi Gawat Darurat di RSUD Cileungsi Berbasis Web Dengan Menggunakan Metode Waterfall
}

\section{Visum Data Administration System for Emergency Installation Registration at Web-Based Cileungsi Hospital Using Waterfall Sistem}

\section{Mulyana Wiguna, Iskandar*}

*Program Studi Teknik Informatika, Sekolah Tinggi Teknologi Muhammadiyah Cileungsi-Indonesia

* Jln. Anggrek No.25 Komplek Perum PTSC, Cileungsi, Bogor, Jawa Barat-Indonesia 16820

\section{Informasi Artikel Article History:}

Submission: 25-09-2021

Revised: 17-12-2021

Accepted: 17-12-2021

\section{Kata Kunci:}

Data Visum; Database, Pelayanan UDG; Waterfall; Website

\section{Keywords:}

Visa Data; Database, Emergency Room Service; Waterfall; Website

\section{* Korespondensi:}

Iskandar iskandar@sttmcileungsi.ac.id

\begin{abstract}
Abstrak
Rumah Sakit RSUD Cileungsi merupakan sebuah Rumah Sakit yang di didirikan di wilayah Kabupaten Bogor yang sudah beroperasi dari Tahun 2012 yang saat ini berkembang dan terakreditasi A pada tahun 2018 yang telah membuka beberapa pelayanan rawat jalan, rawat inap, radiologi, laboratorium, farmasi dan saat ini membuka pelayanan forensik khususnya di bagian IGD, namun dalam pelaksanaan pembuatan visum di RSUD Cileungsi timbul masalah pada administrasi pembuatan Visum et repertum yaitu lamanya pelayanan yang berjalan pada pelayanan maupun pengelolaannya. Dengan adanya masalah tersebut dalam penelitian ini bertujuan membuat sistem layanan administrasi proses visum secara online terkait keperluan data untuk dilakukan visum. Selanjutnya dalam pengembaangan aplikasi menggunakan metode Waterfall dan database MySql. Setelah dilakukan perancangan dan pengujian pada sistem aplikasi visum tersebut menghasilkan performance cukup dalam pembuatan visum. Dengan adanya sistem visum online ini berharap dapat membantu sistem administrasi data visum pada IGD di RSUD Cileungsi.
\end{abstract}

\section{PENDAHULUAN.}

Kemajuan pada teknologi data yang saat ini berkembang sangat pesat, berdampak positif pada kemajuan dan memudahkan dalam pekerjaan untuk manusia[1]. Dalam penerapannya Infotech: Jurnal Informatika Teknologi is licensed under a Creative Commons Attribution-NonCommercial 4.0 International License. 
Sistem Administrasi Data Visum Pada Pendaftaran Instalasi Gawat Darurat di RSUD Cileungsi Berbasis Web Dengan Menggunakan Metode Waterfall

teknologi informasi sudah digunakan dari mulai perusahaan serta instansi pemerintahan sebagai alat dalam suatu pekerjaan serta data. RSUD Cileungsi sudah memberikan pelayanan pada kasus Visum et Repertum dimana pada hal ini dokter memberikan informasi berbentuk hasil pengecekan penderita yang dijelaskan pada lembar Visum et Repertum[2]. Dalam kegiatan penentuan hukum acara pidana di indonesia, terkait keperluan tenaga ahli atau pakar dalam bidangnya diatur dalam KUHP pada pasal 120 ayat (1). Dengan hal tersebut, wajib adanya sistem yang bisa memudahkan pada bagian admin IGD dalam pengelolaan administrasi supaya bisa memberikan pelayanan jadi lebih mudah, cepat dan lebih baik[3].

Dalam pelaksanaannya sistem visum mengalami banyak kendala yang selama ini dilakukan di IGD Rumah Sakit Umum Daerah Cileungsi, sehingga menimbulkan pelayanan visum yang membutuhkan waktu yang lama. Maksud dan tujuan penelitian ini yaitu untuk membangun sistem administrasi yang dapat mengakomodir kebutuhan pada pengelolaan data pemeriksaan Visum et Repertum pada pendaftaran IGD di RSUD Cileungsi supaya menjadi lebih cepat dan baik.

Supaya penelitian tidak terlalu luas, diadakan pembatasan terkait materi yang akan diteliti supaya lebih terarah sesuai tujuan yang akan dicapai adapun terkait permasalahan terkait yaitu sebagai berikut:

A. Perancangan sistem yang dibangun menampilkan registrasi data pasien yang dibutuhkan dalam laporan visum.

B. Pada sistem yang dibangun memberikan kemudahan dalam penginputan data yang memeriksa dan hasil yang diperiksa hingga mendapatkan hasil laporan yang baik pada Visum et Repertum.

C. Aplikasi yang dibuat menggunakan Php dan MySql

Tujuan dari penelitian ini yaitu membuat sistem informasi[4] visum et repertum pada registrasi IGD di RSUD Cileungsi supaya aplikasi sistem nantinya bisa mengelola hasil dari pengecekan Visum et repertum menjadi jadi lebih baik, aman dan lebih cepat dalam pelayanannya.

\section{METODE}

2.1 Metode pengembangan aplikasi

Dalam penelitian perancangan aplikasi sistem administrasi data visum pada registrasi Instalasi Gawat Darurat (IGD) di RSUD Cileungsi dengan metode pengembangannya menggunakan metode waterfall. Langkah-langkahnya terdiri dari beberapa fase yaitu perencanaan, pemodelan, implementasi(konstruksi) dan pengujian. Berikut ini gambar proses SDLC (System Development Life Cycle) serta model waterfall[5][6][7] yang dijelaskan pada gambar 1 dan gambar 2: 


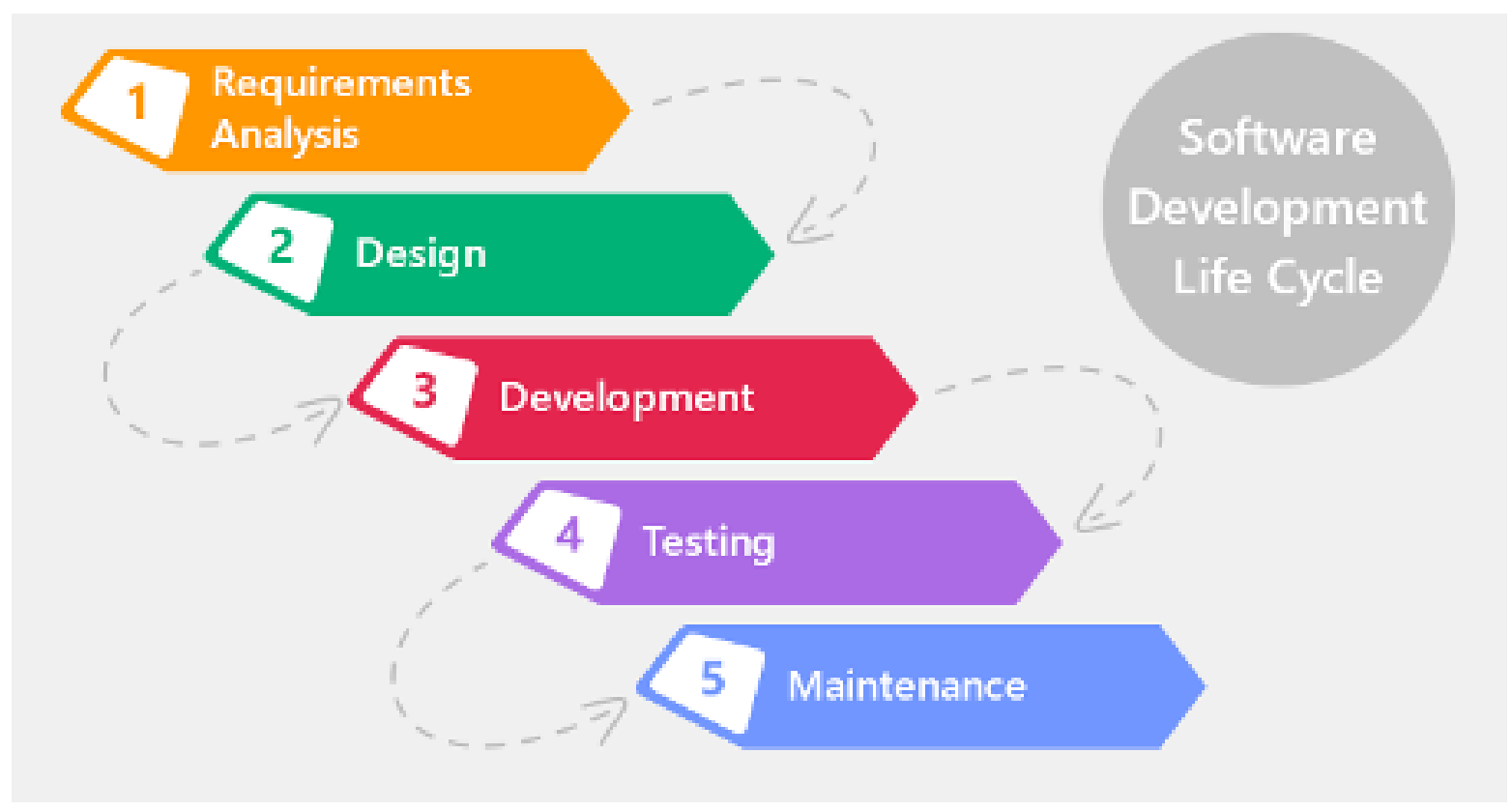

Gambar 1. Metode SDLC [5]

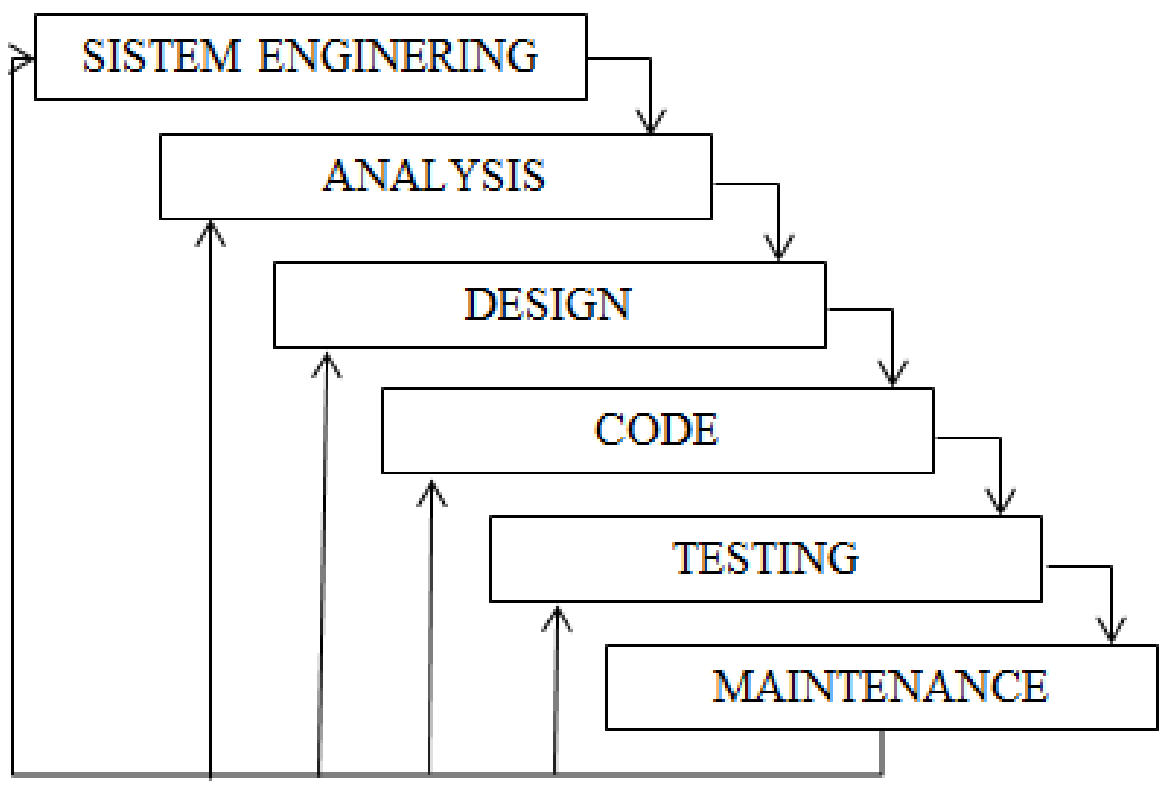

Gambar 2. Metode Waterfall [8]

Tahapan pengembangan software dengan metode waterfall[9] pada gambar 1 adalah sebagai berikut:

A. Requirement

Tahapan requirement ini pengembang harus mengetahui informasi terkait kebutuhan software yang akan digunakan, di antaranya keperluan software untuk user dan batasan perangkat lunak.

B. Proses Desain

Proses desain yang dimaksud adalah membuat alur dari sistem sebelum dilakukan pembuatan code program. Maksud dari desain yaitu untuk memberikan suatu gambaran terkait dengan langkah pengerjaan aplikasi dan juga terkait antarmuka dari aplikasi yang akan dibuat. 
Sistem Administrasi Data Visum Pada Pendaftaran Instalasi Gawat Darurat di RSUD Cileungsi Berbasis Web Dengan Menggunakan Metode Waterfall

\section{Pengintegrasian dan pengujian}

Pengintegrasian dan pengujian, langkah ini dilakukan proses menggabungkan bahan yang sudah dikerjakan dan yang belum. Selanjutnya dilakukan pengujian performance yang bertujuan untuk mengetahui fungsi aplikasi sudah sesuai dengan tujuan dari perancangan atau belum.

D. Operation dan Maintenance

Langkah operasi dan maintenance adalah tahapan terakhir dari beberapa metode, apakah aplikasi tersebut sudah jadi untuk di jalankan tersebut masih perlu perbaikan atau tidak. Tujuannya adalah untuk menyempurnakan suatu aplikasi termasuk dari perbaikan kesalahan dari bug atau error, implementasi dan peningkatan kinerja sistem sesuai kebutuhan jangka panjang.

\subsection{Visum}

Visum et Repertum [10] adalah satu kata atau istilah di dalam ilmu kedokteran khususnya pada ahli Forensik, biasa disebut Visum. Dimana arti dari bahasa latin tersebut yang berarti visa, sedangkan jika dipandang dari segi tata bahasa(etimologi) dapat diartikan tanda melihat (yang terlihat), yang maksudnya meliputi penandatanganan dari semua barang bukti yang ditemukan, disetujui dan juga disahkan. Repertum mengandung arti suatu bentuk pelaporan atas pemeriksaan dokter terhadap pasien(korban) tindak pidana. Sehingga secara tata bahasa atau etimologi Visum et Repertum diartikan segala sesuatu temuan dari hasil pemeriksaan kepada korban[11].

Macam-macam dari bentuk Visum pada Visum Et Repertum seperti terdapat [12] diantaranya sebagai berikut :

A. Visum untuk Perlukaan (termasuk keracunan)

B. Visum untuk kejahatan susila

C. Visum untuk jenazah

D. Visum untuk psikiatri.

Jenis visum tersebut di atas dikenakan pada objek tubuh atau raga manusia[13]. Dalam hal ini visum tersebut dilakukan kepada orang yang berstatus korban tindak pidana, dimana 4 jenis visum tersebut dapat dipergunakan dalam pembuktian dakwaan kepada terdakwa tindak pidana.

\subsection{Teknik analisis}

Teknik analisis merupakan salah satu langkah yang menentukan pencapaian yang maksimal pada sebuah penelitian, dimana langkah ini terdiri dari:

A. Tahapan penelitian

1) Korban (pasien) melaporkan kepada pihak berwajib (polisi) atas kasus yang dialaminya.

2) Pergi ke rumah sakit dan membawa surat permintaan "Visum" dari kepolisian dan didampingi oleh polisi.

3) Pasien, mengisi formulir pendaftaran yang disediakan oleh Admin RS.

4) Administrasi, mendaftarkan pasien dan mengkonfirmasi kepada dokter untuk permintaan visum.

5) Dokter, memeriksa pasien.

6) Dokter, membuat hasil pemeriksaan dan memberikan hasil pemeriksaan kepada admin untuk dibuatkan form visum.

7) Admin, menginput hasil visum yang sudah diserahkan dokter. 
8) Admin memberikan hasil data visum pada polisi

9) Terkait instrumen yang digunakan dalam penelitian ini yaitu berupa soal pertanyaan.

B. Perencanaan

Tahap perencanaan dilakukan oleh peneliti dan pelaku dimana sebagai pelaku pada penelitian adalah admin dan ditentukan mengenai:

a. Pokok materi penelitian

b. Bentuk pertanyaan tentang materi bahan yang akan diteliti

c. Pembuatan butir soal berdasarkan dari perencanaan

\subsection{Teknik pemodelan UML}

Pemodelan menggunakan UML tidak ada batasan secara tegas terkait konsep dan konstruksi dalam UML [14][15][16][17][18], tetapi dalam rangka menyederhanakan kita dapat membaginya menjadi beberapa view.

\section{HASIL DAN PEMBAHASAN}

Perkembangan teknologi informasi semakin canggih untuk diterapkan dalam suatu pekerjaan sehari-hari. Upaya meningkatkan pelayanan yang lebih maksimal harus diimbangi dengan teknologi yang baik. Oleh karena itu pada pendaftaran IGD di RSUD Cileungsi harus adanya sistem administrasi yang dapat mengelola khususnya pada berkas medis kasus tindak pidana yang biasa disebut "Visum et Repertum". Dengan adanya sistem seperti ini semoga dapat mengatasi permasalahan terkait pengelolaan data visum sehingga menjadi lebih baik dan aman.

3.1 Perancangan sistem yang dibangun.

a. Use Case Diagram

Use case diagram merupakan penggambaran interaksi sistem dengan lingkungannya seperti terlihat pada gambar 3 .

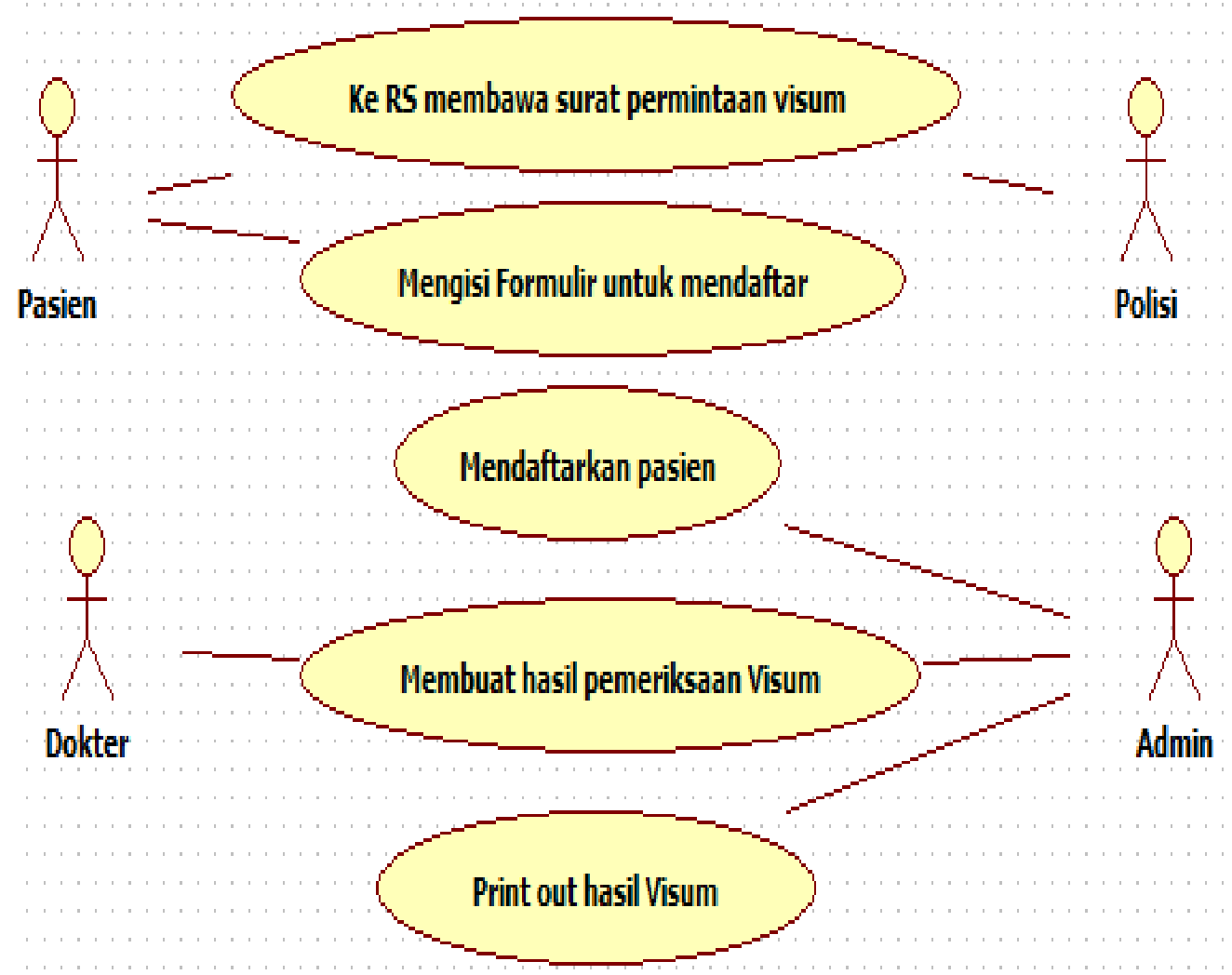

Gambar 3. Use case diagram sistem yang dirancang 
Sistem Administrasi Data Visum Pada Pendaftaran Instalasi Gawat Darurat di RSUD Cileungsi Berbasis Web Dengan Menggunakan Metode Waterfall

b. Use Case Login.

Use case login merupakan penggambaran interaksi login user dengan sistem aplikasi seperti pada gambar 4 .

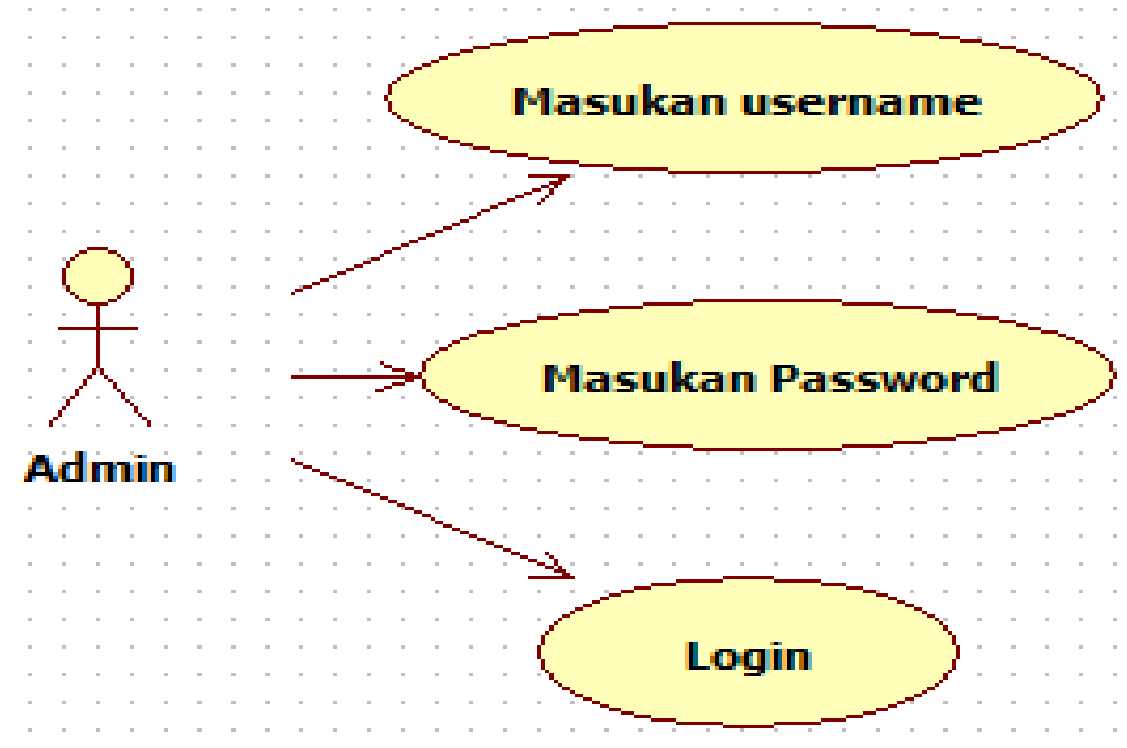

Gambar 4. Use case login

c. Sequence diagram sistem yang dirancang

Sequence diagram merupakan penggambaran operasi, pesan dikirim dan kapan dilakukannya yang terdapat pada sistem aplikasi seperti terlihat pada gambar 5 .

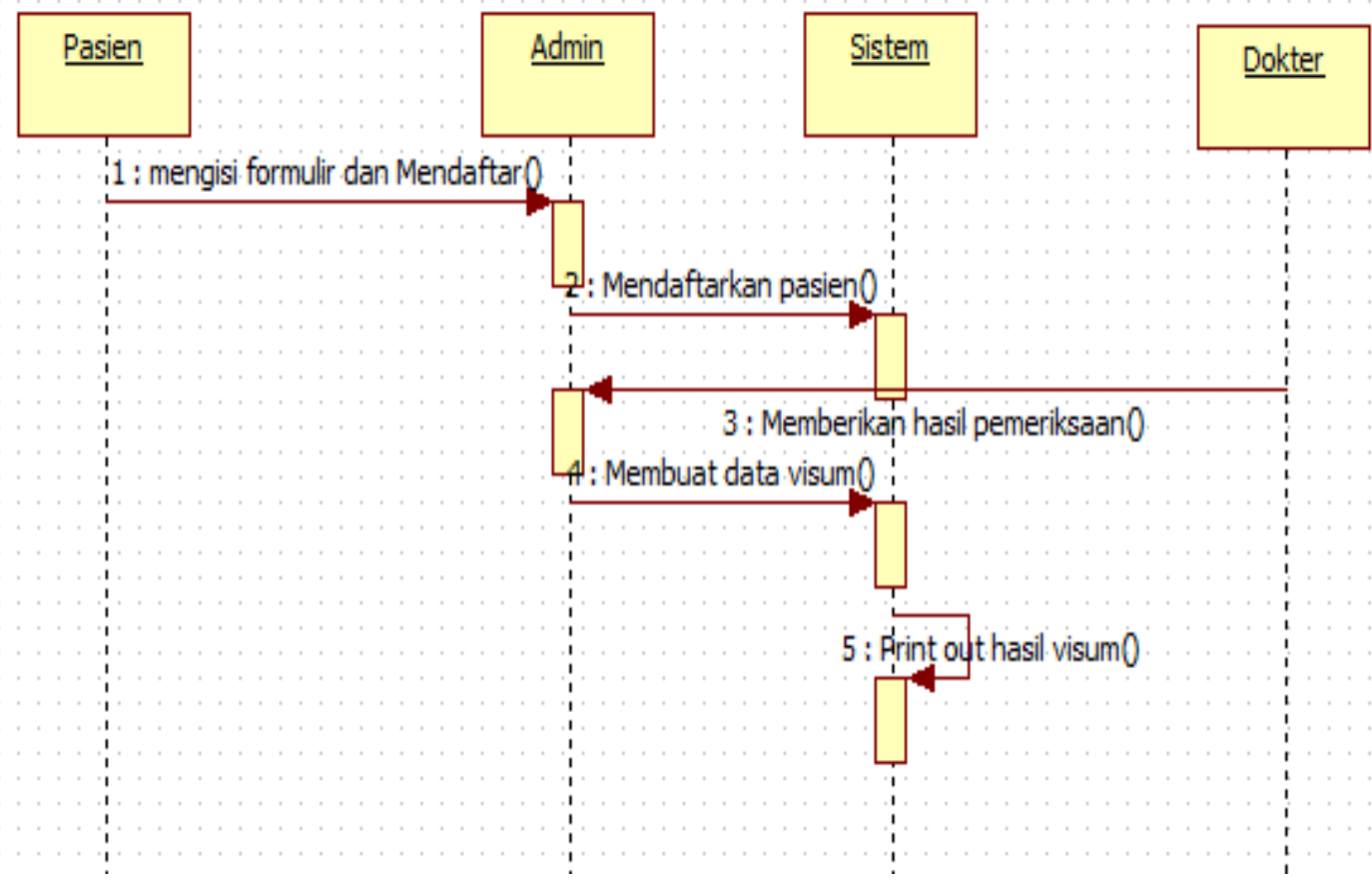

Gambar 5. Sequence diagram sistem yang dirancang

d. Diagram sequence login

Diagram sequence login merupakan penggambaran sender dan passing yang ditangani oleh web service pada sistem seperti pada gambar 6 . 


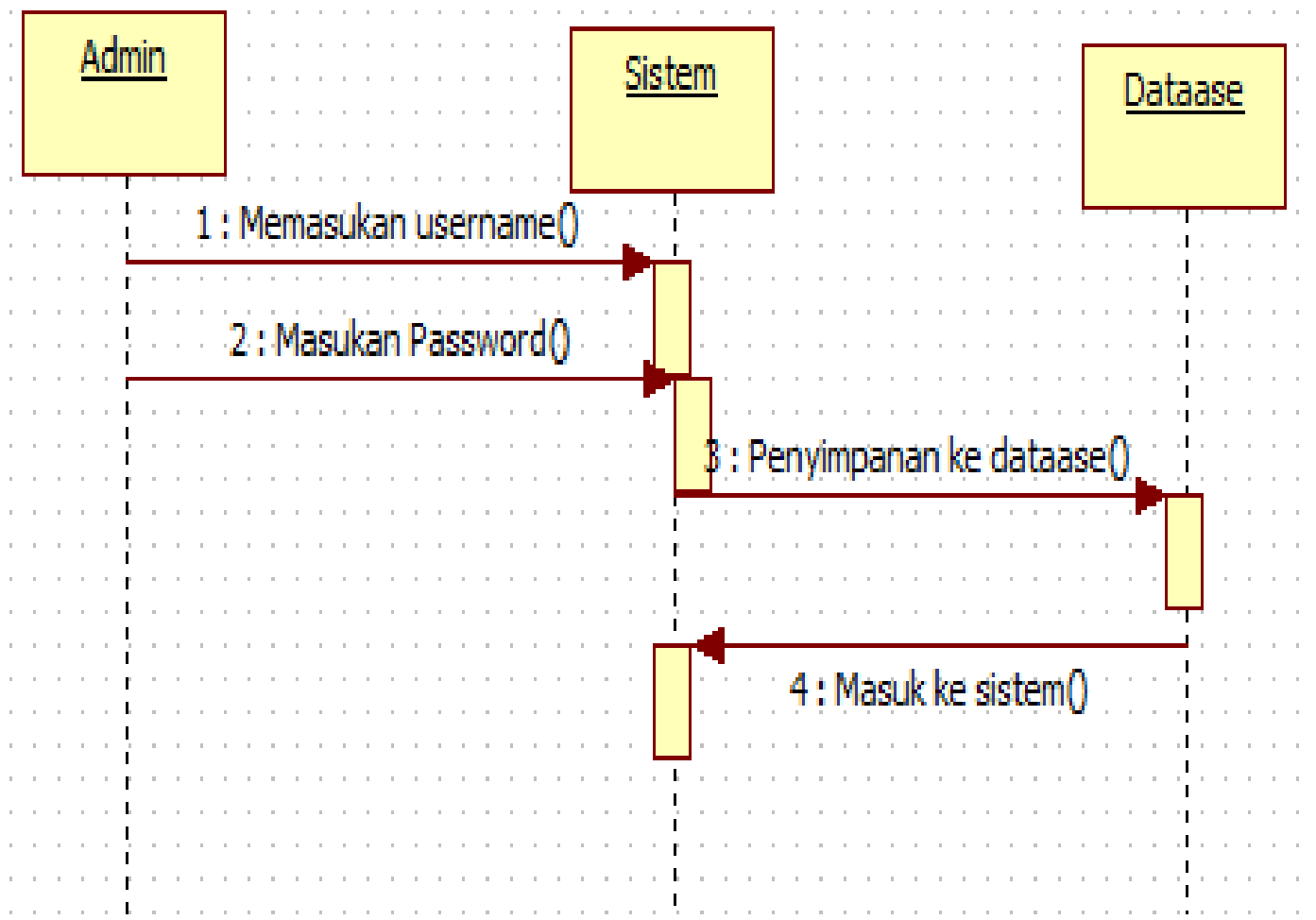

Gambar 6. Diagram sequence login

e. Activity diagram sistem yang dirancang

Activity diagram merupakan penggambaran kegiatan entitas yang ada di dalam sistem seperti pada gambar 7 .

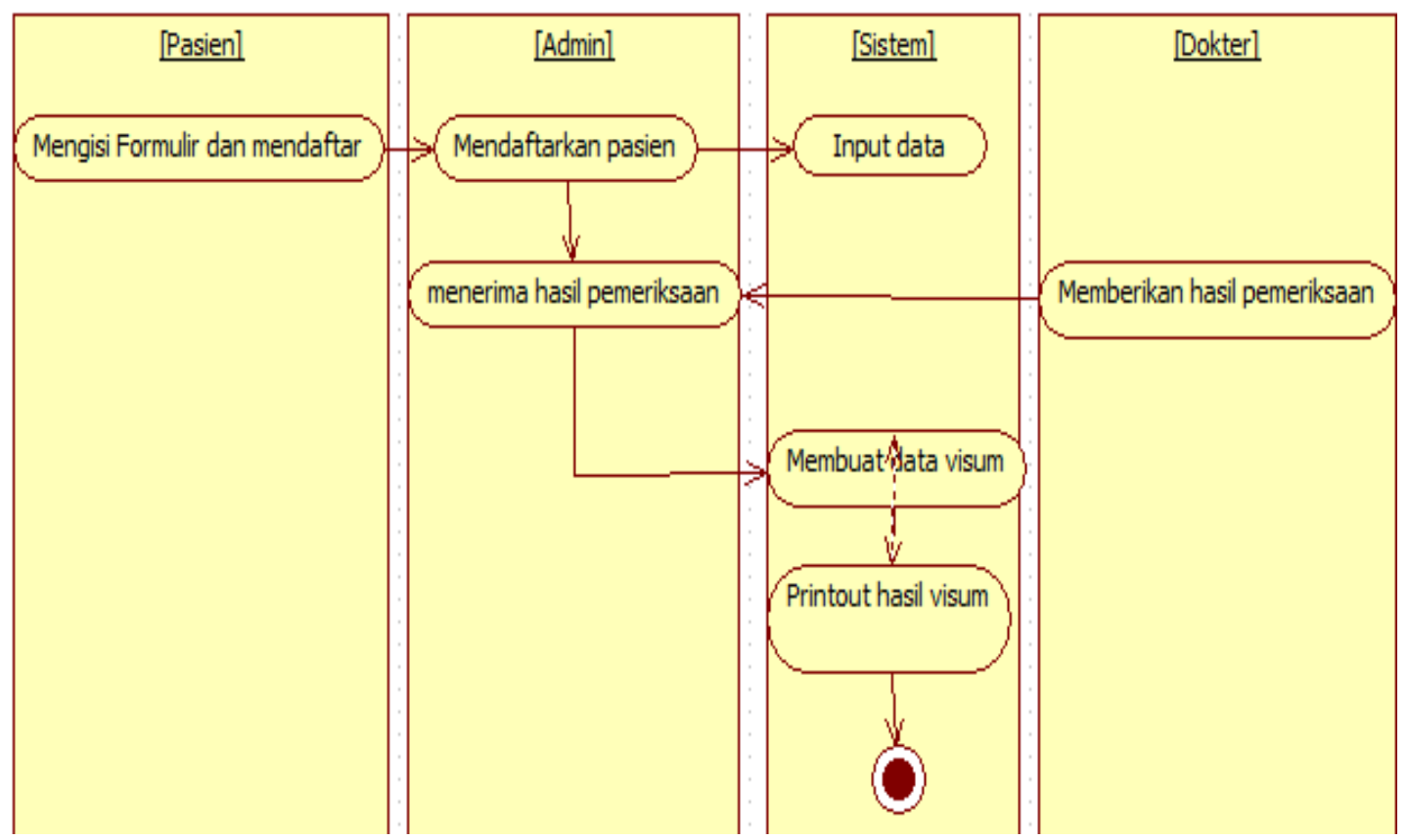

Gambar 7. Activity diagram sistem yang dirancang.

f. Activity diagram sistem login yang dirancang

Activity diagram login merupakan penggambaran kegiatan entitas pada saat login ke dalam sistem seperti pada gambar 8 . 
Sistem Administrasi Data Visum Pada Pendaftaran Instalasi Gawat Darurat di RSUD Cileungsi Berbasis Web Dengan Menggunakan Metode Waterfall

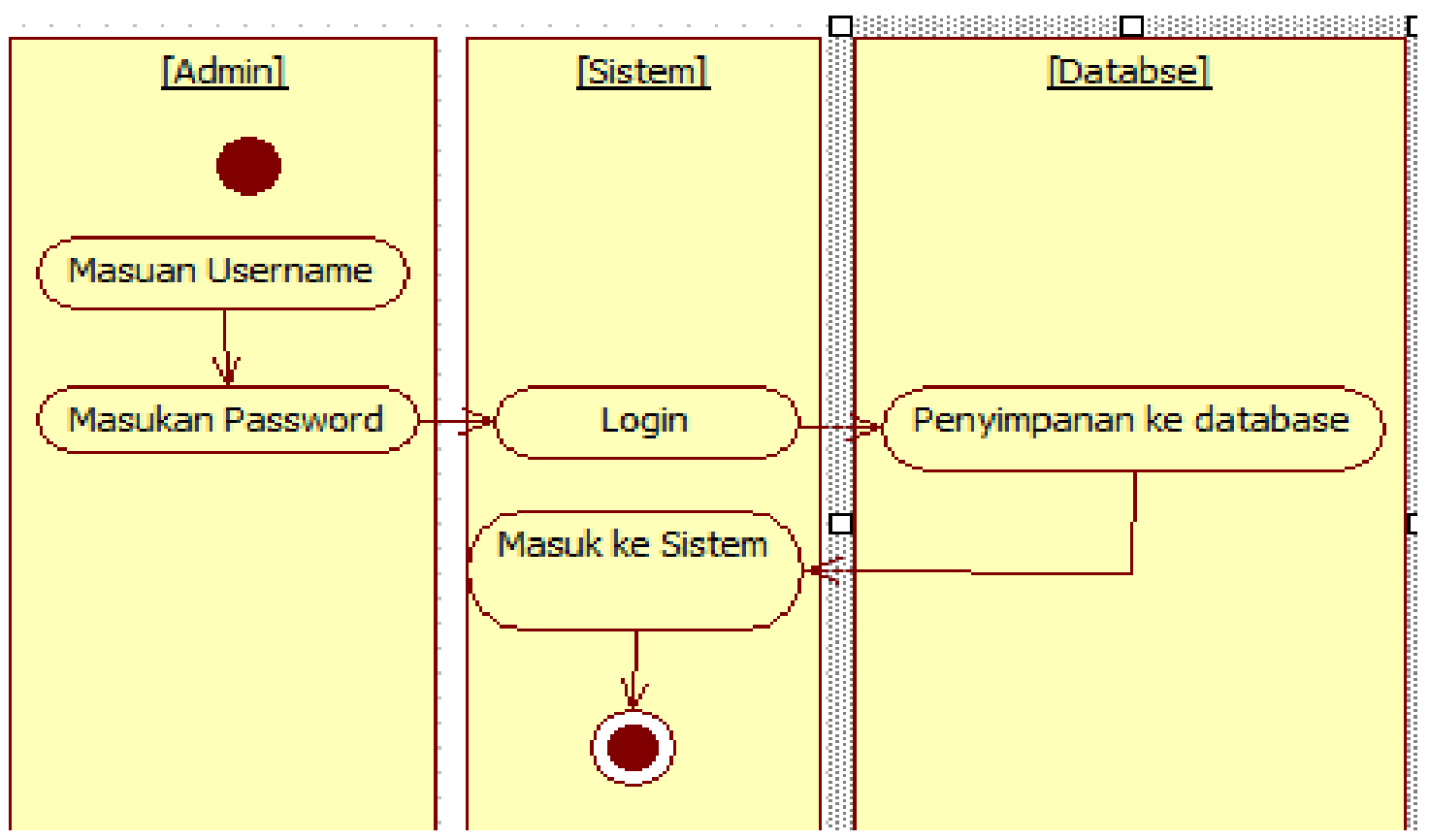

Gambar 8. Activity diagram sistem login sistem yang dirancang

g. Class diagram sistem yang dirancang

Class diagram merupakan penggambaran struktur sistem dari pendefinisian kelas-kelas yang akan dibuat untuk membangun sebuah sistem seperti pada gambar 9 .

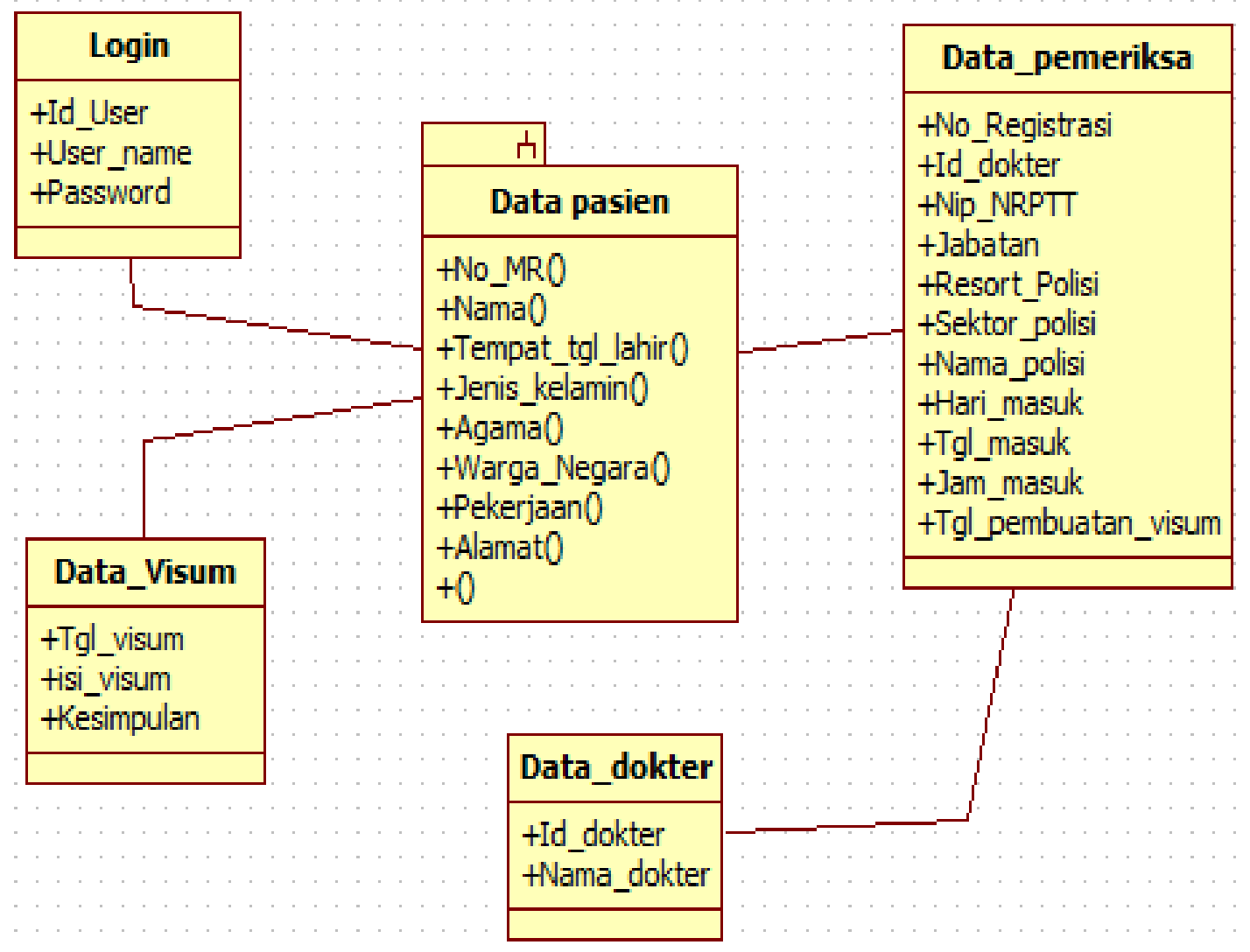

Gambar 9. Class diagram sistem yang dirancang 
h. Perancangan database.

Tabel 1. Data pasien

\begin{tabular}{llll}
\hline Field & Type & size & Keterangan \\
\hline No_MR & Varchar & 8 & No_mr \\
Nama & Text & 30 & Nama \\
Tgl_Lahir & Date & 9 & Tgl_lahir \\
Agama & Text & 8 & Agama \\
Jenis_Kelamin & Varchar & 10 & J_kelamin \\
Warga Negara & Int & 3 & Warga Negara \\
Pekerjaan & Text & 15 & Pekerjaan \\
Alamat & Varchart & 100 & Alamat \\
\hline
\end{tabular}

Tabel 2. Data pemeriksaan

\begin{tabular}{llll}
\hline Field & Type & size & Keterangan \\
\hline Id_dp & Int & 11 & Auto_Increment \\
Id & Int & 11 & Auto_Increment \\
No_Registrasi & Varchar & 20 & NO_register \\
Id_Dokter & Varchar & 30 & Id_Dokter \\
Nip_NRPTT & Int & 20 & Id_Nip \\
Jabatan & Text & 10 & Jabatan \\
Resort_Polisi & Text & 20 & Resort_polisi \\
Sektor_polisi & Text & 25 & Id_Polisi \\
Nama_polisi & Text & 30 & Nama_polisi \\
Hari_masuk & Text & 6 & H_masuk \\
Tgl_masuk & Date & 10 & Tgl_masuk \\
Jam_masuk & Time & 8 & Jam_masuk \\
Tgl_Pembuatan_Visum & Date & 10 & Tgl_Pembuatan \\
No_Reskrim & Varchar & 20 & No.Surat Polisi \\
Tgl_Visum & Date & & Tgl pasien di periksa \\
Isi_Visum1 & Text & & Isi data visum \\
Isi_Visum2 & Text & 250 & Isi data visum \\
Isi_Visum3 & Text & 250 & Isi data visum \\
Kesimpulan1 & Text & 500 & Isi Kesimpulan Visum \\
Kesimpulan2 & Text & 500 & Isi Kesimpulan Visum \\
Kesimpulan3 & Text & 500 & Isi Kesimpulan Visum \\
\hline
\end{tabular}

Tabel 3. Dokter

\begin{tabular}{cccc}
\hline Field & Type & size & Keterangan \\
\hline Id & Int & 11 & Auto_Increament \\
Namadokter & Varchar & 50 & Nama dokter \\
Nrptt & Varchar & 30 & Nomor induk \\
\hline
\end{tabular}

Tabel 4. User

\begin{tabular}{cccc}
\hline Field & Type & size & Keterangan \\
\hline Id_user & Int & 11 & Id_User \\
\hline Nrp & varchar & 100 & \\
\hline Username & varchar & 50 & Nama_user \\
\hline Nama_User & varchar & 50 & Nama_user \\
\hline
\end{tabular}


Sistem Administrasi Data Visum Pada Pendaftaran Instalasi Gawat Darurat di RSUD Cileungsi Berbasis Web Dengan Menggunakan Metode Waterfall

\subsection{Implementasi dari sistem aplikasi visum}

Implementasi sistem merupakan tahapan dari penerapan suatu sistem serta pengujian sistem aplikasi data visum di RSUD Cileungsi. Pengujian di sini meliputi kesesuaian dengan desain perancangan, use case serta antra muka yang akan dirancang. Jika dalam implementasi dan pengujian ini menemukan ketidaksesuaian maka dapat dilakukan perbaikan pada sistem yang dirancang.

Untuk implementasi sistem dan pengujian di antaranya terkait kesesuain antarmuka seperti contoh pada antarmuka login, menu utama seperti pada gambar 10 dan gambar 11 .

A. Form Login

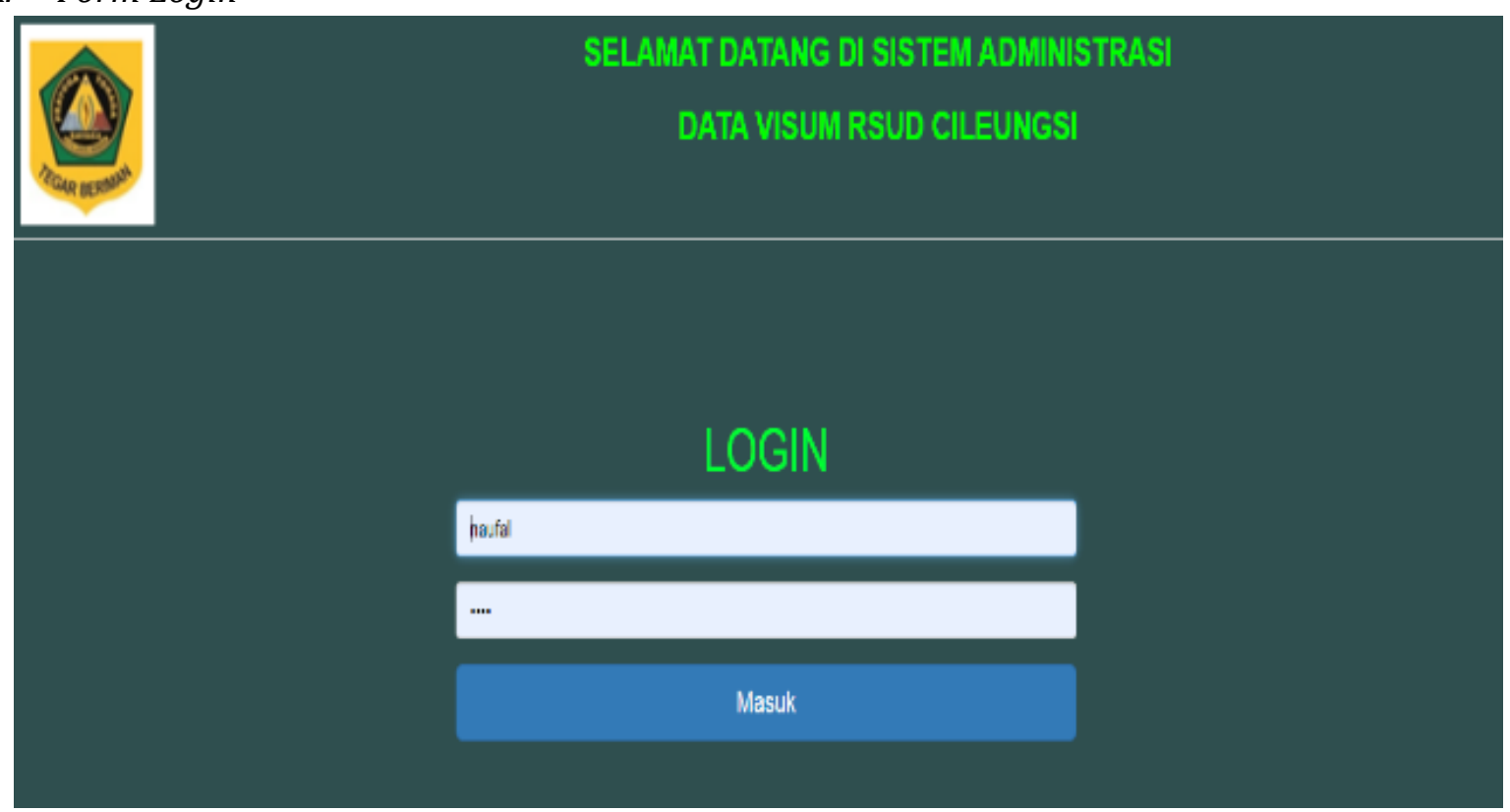

Gambar 10. Antarmuka login

B. Halaman utama

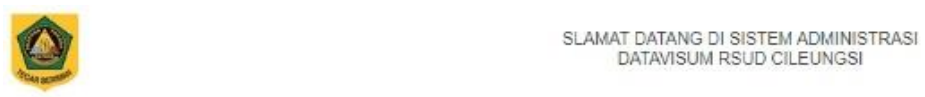

REGISTRASI * MEDICALRECORD * SETTING * USER *

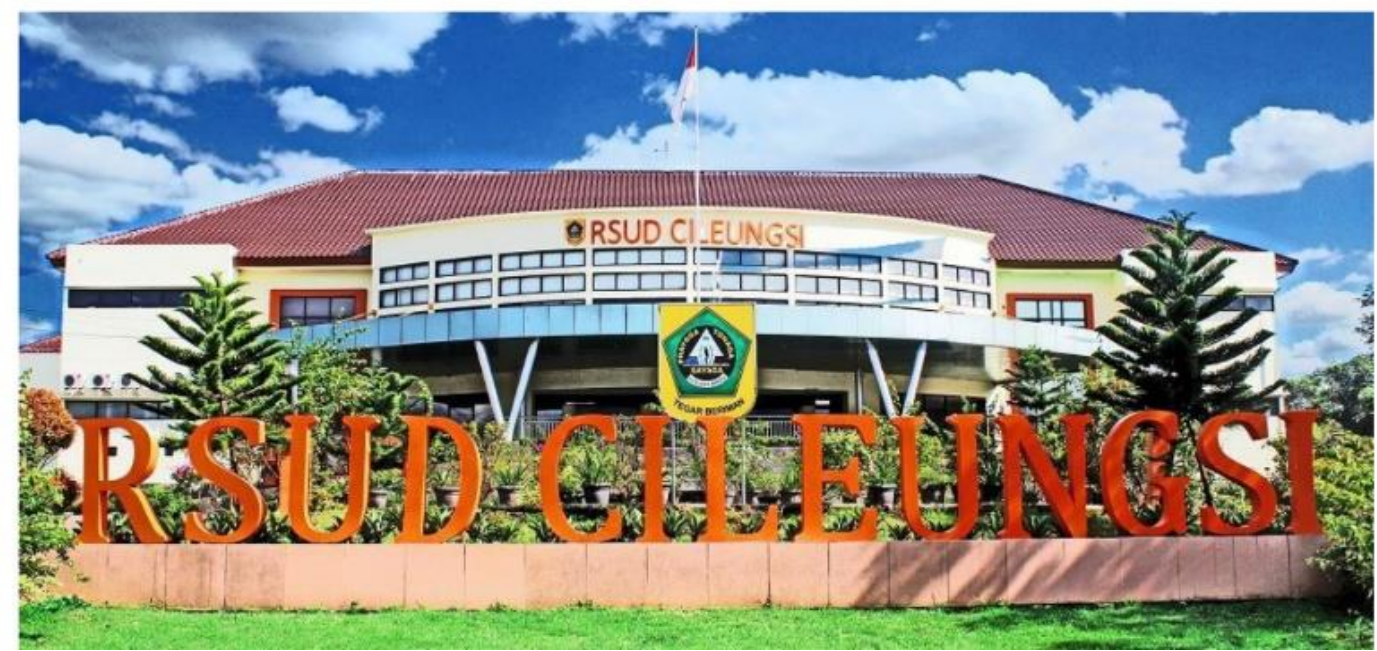

Gambar 11. Antarmuka menu utama 
Di dalam aplikasi sistem visum ini pada menu utama terdapat menu-menu yang lainya di antaranya, menu registrasi pendaftaran online pasien visum, pengisian dan pemeriksaan, pengisian data visum, data visum pasien, menu data pasien, setting dokter dan contoh laporan hasil visum pada pasien seperti pada gambar 12 .

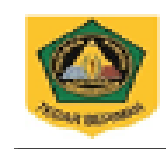

PEMERINTAH KABUPATEN BOGOR RUMAH SAKIT UMUM DAERAH CILEUNGSI Jl. Raya Clleungsi - Jonggol KM.10 Clieungsi Kabupaten Bogor 16820 Telp / Fax (021) 89934667/ (021) 89934666 Email: roudcileungsinthogorkab. go id

"Pro Justicia"

\section{SURAT KETERANGAN PEMERIKSAAN LUKA CVISUM}

Nomor : 001/1/1GD/RSUD/2020

Saya Yang Bertanda tangan dibawah ini, Nama dr. Romanita S.R NRPTT. 2147483647. Jabatan : DR.UMUM, atas Surat Permintaan Pemeriksaan Luka dari Kepolisian Republik Indonesia Resort BOGOR Sektor CILEUNGSI NO Reskrim VR-I/VISUM/Cileungsi Yang Ditandatangani oleh IPDA RATNA S.H menerangkan dengan sesungguhnya bahwa pada hari Kamis, 2020-01-02 09:00:00 wIB , di RSUD CILENGSI, Telah memeriksa seseorang:

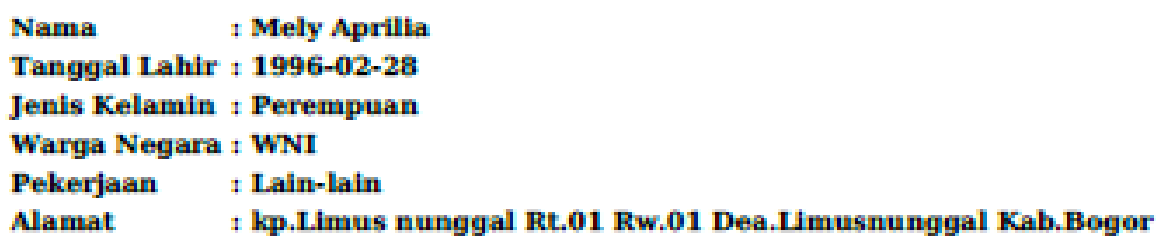

1. Terddapat luka garis memanjang di pergelangan tangan kiri dengan ukuran dua senti meter

2. terdapat luka sobek memanjang dengan ukuran satusamal dua senti meter pada muka atas tangan sebelah kanan

3. terdapat luka memar pada pipi kanan sebelah bawah mata dengan ukuran dua kall satu senti meter

\section{KESIMPULAN}

Telah di periksa seseorang perempuan usia 16 th dengan ciri-ciri rambut panjang sedikit keriting berkulit putih.

Terddagat laka garis memanjang di pergelangan tangan kiri dengan ukuran dua senti mete, terdapat luka sobek memanjang dengan ukuran sahusamai dua senti meter pada muka atas tangan sebelah kanan terdapat luka memar pada pipl kanan sebelah bawah mata

Demikdanlah visum et repertum ini dibuat dengan sebenarnya dengan menggunakan keilmuan sebaikbaiknya, mengingat sumpah sesuai dengan kitab Undang-Undang Hukum Acara Pidana, dam agar dagat di pertanggung jawabkan sebegaimana mestinya

\section{Gambar 12. Laporan hasil visum}

\subsection{Pengujian sistem}

Uji coba dilakukan pada sistem yang dirancang menggunakan persyaratan-persyaratan terkait spesifikasi, metode yang ada pada standar mutu pengujian kelayakan suatu software aplikasi sesuai dengan ISO 9126. Kriteria pengujian meliputi functionality, reliability, usability, efficiency, maintainability dan portability dengan menghasilkan performance dengan kategori baik dan cukup.

\section{SIMPULAN}

Setelah dilakukan penelitian dan perancangan, implementasi dan pengujian sistem pada sistem aplikasi administrasi data visum pendaftaran IGD RSUD Cileungsi yang dilakukan secara 
Sistem Administrasi Data Visum Pada Pendaftaran Instalasi Gawat Darurat di RSUD Cileungsi Berbasis Web Dengan Menggunakan Metode Waterfall

online dapat menangani proses pencatatan, penyimpan, data dan sekaligus penyimpanan data yang berkaitan dengan data visum sehingga proses pelayanan pada administrasi bisa lebih baik, cepat efektif dan efisien. Terbukti dengan hasil pemrosesan data visum yang lebih cepat. Setelah dilakukan pengujian terhadap performance menggunakan standar pengujian ISO 9126 pada fungsi kegunaaan dan keandalan menunjukan performance dengan kategori cukup baik. Hasil implementasi dan pengujian sistem visum tersebut bisa diaplikasikan dalam mengelola administrasi visum di IGD RSUD Cileungsi. Namun sistem aplikasi ini perlu adanya perbaikan karena data visum ini merupakan hal yang private sebagai identitas pasien, jenis visum yang mana data ini bisa digunakan sebagai alat bukti pihak tertentu, sehingga perlu ditingkatkan sistem keamanannya karena sistem administrasi data visum belum dilengkapi support keamanan yang lebih baik untuk mencegah penyalahgunaan pihak lain.

\section{DAFTAR PUSTAKA}

[1] M. Sari, H. Basri, and M. Indriani, "Pengaruh Pemanfaatan Teknologi Informasi, Kompetensi Aparatur Dan Komitmen Organisasi Terhadap Kinerja Manajerial Pengelolaan Keuangan Pada Satuan Kerja Perangkat Kabupaten Pemerintah Daerah,” Pascasarj. Univ. Syiah Kuala, vol. 7, no. 2, pp. 67-73, 2017.

[2] E. R. Barus, T. K. D. A, and A. Arif, "Peranan Visum Et Repertum dalam Proses Pembuktian Perkara Pidana Penganiayaan Biasa yang Mengakibatkan Kematian (Putusan Nomor: 3490/Pid.B/2015/Pn.Mdn)," J. Mercat., vol. 1, no. 1, pp. 79-98, 2017.

[3] Setio Pamuji, Pria Sukamto, Iskandar, and Haryanto, "SISTEM PAKAR BERBASIS DESKTOP DIAGNOSA PENYAKIT KULIT MENGGUNAKAN METODE BRUTE FORCE," INFOTECH J. Inform. Teknol., vol. 1, no. 2, 2020, doi: 10.37373/infotech.v1i2.68.

[4] A. Sutanto, Sistem Informasi Manajemen Konsep dan Pengembangan Secara Terpadu. Bandung: Lingga Jaya, 2017.

[5] Y. Firmansyah and U. Udi, "Penerapan Metode SDLC Waterfall Dalam Pembuatan Sistem Informasi Akademik Berbasis Web Studi Kasus Pondok Pesantren Al-Habib Sholeh Kabupaten Kubu Raya, Kalimantan Barat," J. Teknol. dan Manaj. Inform., vol. 4, no. 1, 2017, doi: 10.26905/jtmi.v4i1.1605.

[6] T. Hartati and I. D. Sintawati, "Implementasi Metode Waterfall pada Perancangan Aplikasi SIPSIBA ( Studi Kasus SMK Muhammadiyah 10 Jakarta )," Ris. dan EJurnal Manaj. Inform. Komput., vol. 5, no. 1, 2020.

[7] D. S. Purnia, A. Rifai, and S. Rahmatullah, "Penerapan Metode Waterfall dalam Perancangan Sistem Informasi Aplikasi Bantuan Sosial Berbasis Android,” pp. 1-7, 2019.

[8] W. Van Casteren, "The Waterfall Model And The Agile Methodologies: A Comparison By Project Characteristics-Short The Waterfall Model and Agile Methodologies," Acad. Competences Bachelor, no. February, pp. 10-13, 2017, doi: 10.13140/RG.2.2.36825.72805.

[9] Sumardiono and Mus Mulyadi Maulana, "PERANCANGAN APLIKASI PESAN TANDING FUTSAL DENGAN METODE WATERFALL," INFOTECH J. Inform. 
Teknol., vol. 2, no. 1, 2021, doi: 10.37373/infotech.v2i1.107.

[10] D. Afandi, "Visum et Repertum Perlukaan : Aspek Medikolegal dan Penentuan Derajat Luka," Maj. Kedokt. Indones., vol. 60, no. 4, p. 188, 2010.

[11] ARSYADI, "Fungsi Dan Kedudukan Visum Et Repertum Dalam Perkara Pidana," J. Ilmu Huk. Leg. Opin., vol. 02, no. 02, pp. 57-64, 2014.

[12] N. Yuliani and A. M. S. Banaja, "Analisis pelaksanaan visum et repertum di rsud karanganyar," Manaj. Inf. Kesehat. Indones., vol. 1, no. 2, pp. 66-69, 2013.

[13] H. Siadari, N. Rochaeti, and B. D. Baskoro, "ARTI PENTING VISUM ET REPERTUM SEBAGAI ALAT BUKTI DALAM PENANGANAN TINDAK PIDANA PERKOSAAN," Diponegoro Law J., vol. 5, pp. 1-18, 2016.

[14] Nugroho A, Rekayasa Perangkat Lunak Menggunakan UML dan Java. Andi offset, 2009.

[15] Verdy Yasin, Rekayasa Perangkat Lunak Berorientasi Objek. Jakarta: Mitra Wacana Media, 2012.

[16] E. F. Wati and A. A. Kusumo, "Penerapan Metode Unified Modeling Language ( UML ) Berbasis Desktop Pada Sistem Pengolahan Kas Kecil Studi Kasus Pada PT Indo Mada Yasa Tangerang," vol. 5, no. 1, pp. 24-36, 2016.

[17] E. T. Montserrat Estanol, Maria-Ribera Sancho, "Reasoning on UML Data-Centric Business Process Models,” no. January 2014, 2013, doi: 10.1007/978-3-642-45005-1.

[18] I. Nugroho, H. Listiyono, and sariyun naja Anwar, "Perancangan Unified Modelling Language aplikasi Sarana Prasarana Pendukung Pariwisata Kota Semarang," Proceeding SENDI, vol. 2, no. 1, pp. 90-95, 2017. 